Paper to be presented to the AFAANZ conference, Gold Coast, Australia, July 2007

\title{
Financial reporting by New Zealand Charities: Finding a way forward
}

\author{
Rowena Sinclair and Keith Hooper, \\ School of Business, AUT University, New Zealand
}

June 2007

Address for correspondence:

Rowena Sinclair, School of Business, AUT University, Private Bag 92006, Auckland 1142, New Zealand, Phone 649921 9999, Fax 649921 9940, Email: Rowena.sinclair@aut.ac.nz

Key words: Charities, not for profit, fund accounting, accounting basis, fixed assets, fund raising expenses

We thank Doris Hui for her invaluable research assistance on this project.

\section{Abstract}

Charities are becoming recognised as playing an important part in communities by furthering government's social objectives through increasing support to disadvantaged members of society. As charities multiply in number it becomes increasingly difficult for fund providers and contributors to determine which charity to support. In New Zealand there is a move towards providing public access to the financial accounts of charities to assist stakeholders in their decision making and to enhance transparency in charities. However, this assumes that these financial accounts are understandable by all stakeholders.

This paper identifies four problems that limit the way forward of the financial reports of charities. The first problem is fund accounting where different titles are used to describe similar funds and specific funds are utilised to remove items from performance measurements. The second problem involves the practice of recording fixed assets as an 
expense rather than capitalisation and depreciation. Third, the accounting basis is a problem for charities where several pledges are made and not received. The final problem surrounds the issue of the allocation of fund raising expenses and the subsequent variable proportion of donations that reach beneficiaries as a result of differing accounting treatments.

To examine these problems eight interviews were conducted involving charitable organisations, auditors and academics that have expertise in charity financial reporting. Finally, some recommendations are proposed that will suggest a way forward with regard to these problems so that the users of the financial reports of charities may benefit.

\section{Introduction}

There are thousands of organisations worldwide that call themselves charities and every day these organisations bombard the general public and businesses with pleas for donations for their worthwhile causes. Determining which charity to support is becoming an increasingly difficult question for the public to answer.

One way in which stakeholders can determine which charity to support is through their financial reports. This has been reflected in New Zealand with a move towards making these publicly accessible in order to enhance the transparency of charities and improve public confidence (Charities Commission, 2006d). This assumes that the financial accounts of charities are understandable and transparent. Unfortunately previous studies (Bird and Morgan-Jones, 1981; Hyndman, 1990; Hines and Jones, 1992; Newberry, 1992; Williams and Palmer, 1998; Connolly and Hyndman, 2000) have shown that this is not the case and that there are some serious problems with the understandability of the financial accounts of charities. We identify four problems which need to be resolved or their impacts lessened to ensure the financial accounts of charities find a way forward. For, as the Strategy Unit in the United Kingdom states, "easy access to accurate and relevant information about charities is essential for real accountability and for trust and confidence in charities" (Charity Commission, 2004, p. 2).

\subsection{Definition of charities}


One of the issues when doing research into the charity sector is the profusion of nomenclature employed to represent the sector. These include: not for profit, incorporated societies, public benefit entities, donee organisations and charities. It is therefore important that the meaning of charities is clarified before their problems are discussed.

Not for profit can be defined as any organisation that is "not carried on for the profit or gain of any member and has rules that do not allow money, property or any other benefits to be distributed to any of its members" (IRD, 2005a, p. 1). Charities are a smaller subset in the NFP sector. The NFP sector can also be split into other components which do not clearly delineate charities.

First, NFP organisations can be either unincorporated or incorporated. Incorporated societies must meet the definition of section 4 of the New Zealand Incorporated Societies Act 1908 which states that they must consist of more than fifteen persons and not be for pecuniary gain. Secondly, the United Nations defines NFP organisations as those meeting five criteria: (1) Has an organisational structure, (2) Not for profit, (3) Institutionally separate from government, (4) Self- governing and (5) Non-compulsory (United Nations, 2003, p. 17).

As can be seen in table 1 NFP institutions are then split into the following categories, some of which would be relevant to charities (Statistics NZ, 2006).

\begin{tabular}{|l|l|}
\hline \multicolumn{1}{|c|}{ NFP categories } & \multicolumn{1}{|c|}{ New Zealand example } \\
\hline Non-profit service providers: education and research & Kohanga reo \\
Non-profit service providers: social services & Plunket Society \\
Non-profit service providers: environment & Barnardos New Zealand \\
International aid and relief organisations & RNZSPCA \\
Arts and culture organisations & World Vision New Zealand \\
Sports clubs & Repertory theatres \\
\end{tabular}




\begin{tabular}{|l|l|}
\hline Advocacy groups & Automobile Association \\
Philanthropic trusts & ASB Community Trust \\
Tangata whenua-based organisations & A \& P associations \\
Political parties & Marae committees \\
Social clubs & NZ Labour Party \\
Unions, business and professional associations & RSAs \\
Religious congregations & NZ Bankers Association \\
\hline
\end{tabular}

\section{Table I: Categories of NFP institutions}

Categories of NFP institutions Public benefit entities is the term used in the New Zealand International Accounting Standard (IAS) 1, paragraph 11.2 where public benefit entities are defined as "reporting entities whose primary objective is to provide goods or services for community or social benefit and where any equity has been provided with a view to supporting that primary objective rather than for a financial return to equity holders" (NZICA, 2004a, p. 12).

As with NFP organisations charities are a smaller subset of public benefit entities. Another meaning that overlaps is 'donee organisations' (Cullen and Dunne, 2006). These are organisations in which individuals who donate gifts of money to them are entitled to a taxation rebate. Donee organisations are defined in section KC 5 of the New Zealand Income Tax Act 2004.

Finally, the definition of charity originally comes from the common law test for charitable purpose contained in the judgement by Lord Macnaghten in Income Tax Special Purposes Commissioners v Pemsel (1891). He classified charitable purposes into four categories (Charities Commission, 2006a) and (MED, 2005):

- Advances education; 
- Advances religion;

- Relieves poverty; or

- Is otherwise beneficial to the community

This is also embedded in section 5(1) of the New Zealand Charities Act 2005 which states "charitable purpose includes every charitable purpose, whether it relates to the relief of poverty, the advancement of education or religion, or any other matter beneficial to the community".

\subsection{Importance of the New Zealand charities sector}

The not for profit sector (NFP) of which charities is an important part is a large and important one in New Zealand and provides crucial services to our communities (Fisher, 2006). The New Zealand government considers that the NFP sector assists them in furthering their own social objectives through, for example, increasing support to disadvantaged members of our society (Cullen and Dunne, 2006).

The New Zealand government is trying to quantify how large the NFP sector is as the New Zealand system of national accounting does not measure voluntary activities so the true size of the NFP sector is hard to determine (Statistics NZ, 2006). The United Nations is also interested in measuring the NFP sector globally and to assist this has published a handbook which recommends statistical methods on which to measure data on NFP institutions (United Nations, 2003). Currently twenty-two countries, including New Zealand (Tennant, Sanders, O'Brien and Castle, 2006), have committed to implementing part of the handbook (United Nations, 2006) showing that having a better understanding of the NFP sector is of global importance.

The New Zealand Minister of Finance and the Minister of Revenue estimate that there are 90,000 NFP organisations within New Zealand who in 2005 received an estimated \$356 million in donations from individuals (Cullen and Dunne, 2006). The New Zealand government wants to encourage continued donations to further assist the government's social objectives. To achieve this goal the public needs to feel confident in donating monies to the NFP sector, in particular charities. 


\section{The literature}

\subsection{Finding a way forward for charities' financial accounts}

In New Zealand the Minister of Finance and the Minister of Revenue (Cullen and Dunne, 2006) feel that increases in the accountability and transparency of charities will improve public confidence. To enhance the transparency of the charities sector the government considers that registering charities will provide the public with greater confidence (Saywell, 2006). This has seen the enactment of the Charities Act 2005 which in section 24 details the information required on the charities' register including an annual report. The draft annual report form requires charitable entities to provide a copy of its financial accounts (McLay, 2006). The New Zealand Minister of Commerce says that financial reports will need to be provided regardless of the income level of the charity (Wilson, 2004). As an incentive to ensure charities register, only registered charities will retain their income tax-exemption status (Charities Commission, 2006b). The importance of financial accounts in making decisions has been shown in the United Kingdom where a survey of 1000 people was conducted by the Charity Commission (Framjee, 2004). 60\% of respondents felt that, "the ability to compare important information between charities would affect their decision about which charity to support" (Framjee, 2004, p. 89).

In New Zealand, where there has been little supervision of charitable entities (McLay, 2006) to further enhance accountability a Charities Commission has been set up. Their role, as well as setting up the registration of charities, is to monitor annual returns submitted by charitable organisations which the government believes will assist in promoting public trust and confidence in the charitable sector (IRD, 2005b). This will, hopefully, ensure that charities will not be let down by their trustees (Siveter, 2004), which means that trustees will have to start behaving and acting appropriately, according to Siveter (2003), and thereby further enhance public confidence.

The financial accounts which form part of the annual report will be available to the general public under section 28 of the Charities Act 2005. Raising to prominence the financial accounts of charities will further press the requirement for accounts that are understandable and transparent to potential donors who may view the Charities Register to 
obtain information about a particular charity. Such wider public dissemination highlights the need to clarify some of the ambiguities in charity accounts, especially those identified by previous studies (Bird and Morgan-Jones, 1981; Hyndman, 1990; Hines and Jones, 1992; Newberry, 1992; Williams and Palmer, 1998; Connolly and Hyndman, 2000).

\subsection{Problems limiting the way forward of charities' financial reports}

The American Accounting Association (AAA) and the Accounting Standards Board (ASB) in the United Kingdom defines accounting as being concerned with the provision of economic information to permit informed judgments and economic decisions by the users of information (AAA, 1966; ASB, 2005). Hyndman (1990) identified two main users of charities' financial accounts: resource providers - funding bodies (like the Government) - and contributors - those among the general public who donate to charities. However, accounting standard bodies like the Financial Accounting Standards Board (FASB) in the United States focus their reporting requirements on resource providers (FASB, 1980) rather than contributors (Hyndman, 1990).

When developing their NFP financial reporting guide in New Zealand, the New Zealand Institute of Chartered Accountants (NZICA) also focused on the need to demonstrate accountability to external users such as funding providers (NZICA, 2006, p. 103). Hyndman (1991) considers that accountability to contributors is not discharged in the most effective manner so as to provide appropriate information to contributors, charities should be more aware of contributors' needs. Moreover, Hyndman's (1990) study of 156 contributors indicates that the information that contributors consider important is generally not disclosed.

The Charities Commission (2006c) identifies thirteen stakeholder groups including the general public, local government, businesses, professional advisors, community and voluntary sector groups which in various ways support charitable institutions. At present, the information provided in charities' financial accounts focuses on meeting the needs of funding providers, while not necessarily addressing the requirements of other stakeholders. This issue was explicitly highlighted by NZICA who considered that further research needs to be undertaken on identifying stakeholder information needs (NZICA, 2005) 
In the United Kingdom the Charity Commission interprets transparency and accountability as "providing relevant and reliable information to stakeholders in a way that is free from bias, comparable, understandable and focused on stakeholders' legitimate needs" (Framjee, 2004, p. 89). It is therefore important to clarify the transparency of financial accounts which will increase the accountability of charities to both contributors and resource providers by ensuring that there is sufficient information for all stakeholders of the financial accounts to base their opinion on.

The most significant research that looked at the transparency of the financial accounts of charities was Bird \& Morgan-Jones (1981). They analysed the accounts from eighty-five large fund raising charities in the United Kingdom and identified a number of weaknesses in the accounts of charities including: the format of accounts; the treatment of legacies; the treatment and disclosure of expenses; the use of fund accounting and; the treatment of fixed assets. With the advent in New Zealand of publicly accessible financial accounts of charities, a preliminary study was undertaken to determine whether some of the weaknesses identified in Bird \& Morgan- Jones (1981) also applied in New Zealand. The study focused on four areas of ambiguity: (1) fund accounting, (2) treatment of fixed assets, (3) accounting basis and (4) fund raising expenses.

\subsection{The problems with fund accounting}

Fund accounting is commonly used in charities and is a system of separating assets, liabilities, equities, revenues and expenditures into several different entities (Wacht, 1991, p. 71). These funds "are like a collection of cookie jars" (Herzlinger \& Sherman, 1980, p. 8) where monies for different activities are stored separately and you can only eat i.e. use the appropriate cookie, for a specific purpose. Such separation could be the result of a donor imposing restrictions on the funds that they contributed.

Herzlinger and Sherman (1980) support the use of fund accounting in charities on the grounds that "the fund accounting statements provide three essential pieces of information on resources: their purpose, the legal limits on their use attached by the donors, and the revocable decisions made by the board on their use" (Herzlinger and Sherman (1980, p. 96). They believe that fund accounting is a vehicle through which the trustees of a charity can 
fulfill their legal obligation as to the use of the contributed funds according to the restrictions imposed by donors. Unlike business accounting, any unspent restricted funds may have to be returned to the donor or be maintained in the restricted fund for re-use for the original purpose (Herzlinger \& Sherman, 1980).

Problems with fund accounting include; (1) different titles to describe similar funds (Bird and Morgan-Jones. 1981); (2) money being transferred illegally among funds (Herzlinger and Sherman, 1980) and (3) stakeholders not understanding the difference between surpluses and funds, for example, surpluses can be used without restrictions whereas some funds must be used for the purposes for which they were created. Moreover, the complexity of fund accounting is further demonstrated by NZICA who identify eight accounting treatment for different types of bequests/funds (NZICA, 2006).

New Zealand's Statement of Concepts (NZICA, 1993) does not mention fund accounting practices and the Glossary recently released by the Charities Commission (2006e) also has no definition of funds. There is in fact little attention paid to fund accounting in New Zealand despite some charities using differing forms of fund or reserve accounting (Newberry, 1992). In fact, Walker (2004) refers to fund accounting in New Zealand as the perennial problem.

\subsection{The problems with fixed assets}

Fixed assets are tangible assets that have future economic benefits controlled by an organisation (NZICA, 1993). The balance sheet of a charity should reflect all assets that are under the control and responsibility of a charity (Bird \& Morgan-Jones, 1981). The question is whether fixed assets purchased by a charity of gifted to a charity should be capitalised and depreciated in accordance with generally accepted accounting practice.

In the United Kingdom, Bird and Morgan-Jones (1981) surveyed 85 large charities to discover that some charities do not depreciate their fixed assets. Other charities write-off assets on purchase and many others do not disclose their depreciation policies. The immediate write-off of fixed assets to revenue account and the omission of fixed assets from the balance sheet do not give a true and fair view of the charity's financial position at 
the year end. Even among the charities that do depreciate their fixed assets, the fixed assets are often not depreciated consistently over their useful lives. With regard to the depreciation of fixed assets acquired by gift, Bird and Morgan-Jones (1981) believe that they should be treated in the same way as those fixed assets acquired by purchase.

Hines and Jones (1992) conducted a longitudinal study of 40 large UK charities' reporting practices from 1988 to 1990, and discovered that there are still charities who do not depreciate their fixed assets, which is not in compliance with the United Kingdom's Statement of Recommended Practice (SORP) (Charity Commission, 2005). Hines and Jones (1992) suggest several possible reasons why charities do not depreciate their fixed assets:

- If capital assets are purchased by using the donee contributions, there is no cost to the charities. Therefore, there is no need to cover the cost from revenues and no depreciation charge is needed. This argument assumes that the fixed assets will either not be replaced or when they are there will be a fresh set of willing donors.

- Charities may feel that depreciation is not consistent with fund accounting, which reflects a receipts and payments situation since depreciation is an expense not a payment.

- Charities may feel that fixed assets are provided by past generations for current capital needs, so future needs should be provided by future generations. There is therefore no need for the current users to provide for depreciation.

- Charities prefer to expense fixed assets at once because it would reduce their reported surplus and the level of fixed assets held. This would portray an appealing image of a lack of funds. It may be argued, however, that an impoverished image may also be achieved by capitalising their fixed assets and then depreciating them to reduce income.

It is of interest to further investigate why the charities are not willing to depreciate their fixed assets as a normal practice. Williams and Palmer (1998) conducted a survey of 83 UK charities' accounts by using Bird and Morgan-Jones's 1981 survey as a benchmark. Williams and Palmer (1998) conclude that there are considerably more charities capitalising and depreciating their fixed assets than those surveyed by Bird in 1981. For those charities who do not depreciate their fixed assets, their reasons (Williams and Palmer, 1998, p. 276) are: 
- The assets were being maintained at their "current condition", and so they were not depreciated; and

- The charity was confident that capital grants would be available to replace the assets. Similar weaknesses in fixed assets reporting were found in New Zealand charities. Newberry (1992) surveyed 29 charities which provided audited financial reports and found that four charities were not following the appropriate accounting standard.

The unacceptable practices are:

- Fixed assets are not capitalised and are written off as expense immediately; and

- Fixed assets purchases are deducted from net assets and the amounts actually purchased are not disclosed (What the debit and credit entries could be to reduce total assets by deducting assets purchased continues to puzzles us but apparently it is done).

The acceptable accounting practice is to recognise fixed assets purchased or donated is to (1) capitalise, and (2) depreciate them as appropriate over their useful life (NZICA, 2006).

\subsection{The problems with the accounting basis}

The third problem relates to the accounting basis used. Generally, accounts of an entity are prepared on either a cash basis or an accrual basis. Where donations are received the basis should be cash rather than accrual basis as large amounts of donations could be pledged but only a few pledges honoured. This was the case with the 2004 Boxing Day tsunami where the United Nations only received a tenth of what had been pledged (Radio New Zealand, 2005).

Bird and Morgan- Jones (1981) suggest that in between a cash basis and an accrual basis, there are two other accounting bases, a modified cash basis (receipts recorded on a cash basis, expenditure on an accrual basis), and a modified accrual basis (revenues recorded mainly on an accrual basis but some on a cash basis). The accrual basis is a fundamental accounting concept in preparing financial reports. Financial reports prepared on an accrual basis inform users of the transactions involving not only the payment and receipt of cash 
during the period reporting, but also the obligations to pay cash in the future and the resources that represent cash to be received in the future.

\subsection{The problems with fund raising expenses}

Finally, there is often ambiguity over the treatment of fund raising expenses, donors may be concerned to know what proportion of funds raised are taken for general overheads, particularly with regard to specific purpose funding. Some charities are very transparent about this, for example, Care Foundation, a New Zealand charitable trust which focuses on child safety, confirmed that they kept $75 \%$ of donations for overheads with consequently only $25 \%$ going to beneficiaries (Henderson, 2002). For many fund raising charities the problem is how overheads should be allocated to fund-raising projects and what is an appropriate benchmark.

\section{Research questions and methodology}

We identified eight research questions which related to the four problems. The eight research questions were investigated through interviews. We decided that interviews were the most appropriate research approach as it would provide the best possible understanding of the problems. The interviews were conducted in the interviewee's office in order to allow the researcher and the participant interacting with each other freely to develop unexpected themes. The research consisted of eight in-depth interviews. These were conducted with two charitable organisations, three auditors and three academics that have expertise in charity financial reporting. The qualitative research principle is that interviews are carried on until each research problem is 'saturated' (Morse, 1995).

\subsection{Fund accounting:}

RQ1. Should a standard terminology be used for different types of funds?

RQ2. Do you agree with categorisation of funds generally into unrestricted and restricted?

RQ3. What motivations do charities have to establish funds? 


\subsection{Fixed assets:}

RQ4. How should the fixed assets purchased be treated in a charitable organisation?

RQ5. Should fixed assets purchased be depreciated?

RQ6. Should fixed assets donated be treated in the same way as those fixed assets purchased?

\subsection{Accounting basis:}

RQ7. Should charity accounts be prepared on an accrual basis, cash basis or modified appropriately?

\subsection{Fund raising expenses:}

RQ8. How should overheads be allocated to fund-raising, especially with regard to specific fund raising events?

The following section will present the interview outcomes as identified: (1) fund accounting, (2) treatment of fixed assets, (3) accounting basis and, (4) fund-raising expenses. 4. Interviews Outcomes

\section{Interview outcomes}

\subsection{The problems with fund accounting}

There is still a lack of consistency in the titles used. The two auditors interviewed concur that charities use many different titles of funds to account for funds for different purposes. The most common titles used are general fund, accumulated fund, capital fund and endowment fund. One auditor describes this type of fund accounting as "jam-jar accounting" to reserve funds for a different purpose which is similar to the view of Herzlinger and Sherman (1980).

The Chief Financial Officer (CFO) of one charitable organisation cites an example that titles of funds may have different definitions in different charities. One charity uses designated 
funds which mean that the funds are restricted by the donors, whereas in another charity designated funds are funds that are not restricted by the donors, but are set aside by the charity for a particular purpose. This lack of consistency in terminology leads to confusion for the different users of the financial reports.

The reasons for establishing funds suggested by the interviewees are quite diverse. The CFO of one charity said that "some charities may have a motivation to try to confuse the readers of the accounts" by transferring money into specific funds and beyond public scrutiny so as to strengthen appeals to potential donors on the grounds of urgent need. For example, sometimes money is transferred from general fund to specific fund to make the charity appear short of funds. He acknowledges that this practice is not good, but it is what some charities do.

It should be appreciated that fund accounting is a particular type of accounting that is different from commercial practice, which could make it harder for the user, who is unfamiliar with charities accounting, to understand. The lack of specific terminology in New Zealand means that the use of fund accounting in charity financial reporting becomes a charity's choice. The titles of funds presented in the financial statements, therefore, largely depend on the professional judgment of the preparers. This gives rise to the proliferation of different terms to describe similar types of funds, which in turn causes confusion to the users of the financial accounts.

In defence of fund accounting, Herzlinger and Sherman (1980) argue that the problem of the complexity of fund accounting is not resolved "by simplification but by better education of users about the meaning and purpose of the components of a fund accounting statement and by greater accessibility to these statements" (Herzlinger and Sherman, 1980, p. 104). However, if the financial statements of a charity are too complex to comprehend, the interest of the stakeholders in the charity reports would be discouraged.

Making financial reporting too complicated to understand might minimise the motivation of the information users to look at the charity accounts for decision making purposes. To clarify this it is proposed to determine whether the format originally recommended by Bird and Morgan-Jones (1981) would provide transparency. Bird and Morgan- Jones (1981) 
proposed to separate funds into unrestricted fund, restricted fund, building and equipment fund and endowment fund.

\subsection{The problems with fixed assets}

The study indicates that all interviewees (100\%) agree that fixed assets should be treated in compliance with financial reporting standards. This means that fixed assets purchased by a charity should be capitalised and depreciated over the asset's useful life. One academic further suggests that fixed assets should be revalued annually and subject to an impairment test by comparing their net book value and their net realisable value.

Impairment loss should be charged to the income account in compliance with the New Zealand International Accounting Standard (IAS) 36 (NZICA, 2004b). However, many of the interviewees do comment that some charities, particularly the small charities, are not capitalising their fixed assets. These charities are more focused on receipts and payments: where the money comes from and what they spend it on. The CFO of one charity condemns as unacceptable practice what is, in effect, immediate one hundred per cent depreciation. Bird and Morgan-Jones (1981) also confirm that many small charities only use receipts and payments accounts. This practice contravenes the New Zealand Not-for-Profit reporting guide paragraph 4.108 (NZICA, 2006) which states that all property plant and equipment be measured at cost or if donated measured at fair value.

In relation to fixed assets donated, there is a consensus amongst the interviewees that the fixed as- sets donated should be treated in the same way as those fixed assets purchased. One academic believes that whether fixed assets are purchased or donated, they "comprise an integral part of the financial position" of a charity. Another academic further stresses that the assets donated should be separately labeled to differentiate them from those fixed assets purchased by the charities themselves. The donors may put such restrictions on the donated fixed assets that they cannot be sold.

Generally, no reasons have been identified to justify that the fixed assets donated should be treated differently from the fixed assets purchased. In response to the proposition from some charities that fixed assets kept in good condition need not be depreciated (Williams 
and Palmer, 1998), most of the interviewees felt that such a proposition was not justified by the principle of allocating the cost of the assets over their useful life. One interviewee added that accounting for depreciation follows the matching principle that the cost of purchasing a fixed asset spreads over the period in which it is expected to generate revenue. It assumes that under normal circumstances, assets are worn out at the end of their useful life except buildings which might appreciate over time; whereas in some cases, fixed assets become impaired or even obsolete due to technological advancement. Another interviewee suggests that where the fixed assets are being maintained at their current condition, the charity should estimate their useful life longer rather than choose not to depreciate them.

One auditor points out that some charities may get confused between depreciation and cash flows. Depreciation is an accounting treatment of consuming an asset, whereas replacement of an asset de- pends on the availability of cash flows. Therefore, the argument from some charities that capital donations would be available to replace the assets was not accepted (Williams and Palmer, 1998). One auditor also pointed out that expecting a capital donation involves uncertainty and that is a fair- ly aggressive financial strategy. Other interviewees added that the realisation of an uncertain capital donation is a windfall gain rather than a long-term financial strategy.

\subsection{The problems with the accounting basis}

There are diverse opinions amongst those interviewed as to whether the financial accounts of charities should be prepared on a modified accrual basis. However, some $62 \%$ of interviewees agree to the use of a modified accrual accounting basis in preparing financial reports of charities. While the remaining interviewees (38\%) oppose the use of a modified accrual basis for the reason that only an accrual basis can reflect a true and fair view of the charity's financial results and position.

Most of the interviewees who support the use of a modified accrual basis recognise the difficulty in enforcing payment of donations that are promised by the donors. One auditor emphasises that they are just promises and donors consider that there is no contractual obligation for them to pay. These promises are uncertain and unreliable. There is no guarantee that donations promised would be received in the future. When the charity is 
certain that these promises are reliable and measurable, these promised donations should be accounted for on an accrual basis. For example, in some cases where money has been spent on a particular project anticipating that income of donations will be effectively coming, such income should be accounted for on an accrual basis.

One CFO considered that whether the accounts of charities should be prepared on an accrual basis depends on the size of a charity. For a large charity, accounts should be prepared on an accrual basis, whereas for a small charity, accounts should not necessarily be prepared on an accrual basis. He continues by giving examples to illustrate the inappropriateness of adopting an accrual basis in preparing charity accounts in some circumstances. For example, a charity is informed by the executors of an estate that the charity is going to receive some money from the estate on the conditions that the surviving spouse and all the children have passed away. This may occur 50 years later. If this income is accounted for on an accrual basis, it would distort the financial position of the charity as the accounts receivable would not be settled in the near future.

Another example is that as a result of an appeal to meet the target for the year, a special donation is received by a charity close to the end of the financial year. That income is not going to be spent until the following financial year, in principle, that income should be accounted for as deferred income on an accrual basis. The CFO, however, comments that using accrual accounting in such a situation does not add any value to the organisation or the users of the financial statements. A modified accrual basis might be appropriate to account for income received during the reporting period.

The CFO further suggests that there may be a number of financial reporting standards to prescribe a separate treatment for charities under certain circumstances. One trustee of a charity comments that when a charity adopts a modified accrual basis in preparing its accounts, notes to accounts should be disclosed to inform the users of the revenues that have not been accounted for in the period reporting either as deferred or accrued income. An academic interviewed suggests that a materiality test should be used to determine whether to use a cash basis or an accrual basis in preparing charity accounts.

\subsection{The problems with fund raising expenses}


Views from those interviewed ranged from not allocating to fully allocating the overhead of administration costs to fund-raising projects. Two interviewees (25\%) believe that there is no need for allocating administration costs to fund-raising projects as they are the costs of running the charity as a whole. The administration costs are incurred regardless of fundraising activities. Four interviewees (50\%) suggest that allocating the administration costs to fund-raising projects would be appropriate to inform the contributors of the "fair cost of a fund-raising activity". This practice of cost allocation follows the matching principle. Two interviewees (25\%) argue that allocating overheads is problematic in financial reporting. It depends on which method of overhead allocation a charity chooses to adopt and the method chosen is usually "unverifiable".

\section{Finding a way forward for charities' financial reporting}

To find a way forward for charities' financial reporting the four problems identified need to be resolved or their impacts lessened in order that informed judgments and decisions can be made by the users of financial information.

\subsection{Fund accounting}

With regards to fund accounting, the study found that charities use many different titles to depict funds, indicating a need for standardised terminology to account for the different titles of funds to enhance comparability and consistency. This terminology needs to be clearly understood by the users of the financial reports.

Some eighty-eight percent of the interviewees responded favourably to the suggestion of standard terminology to account for the different titles of funds. The reasons supporting their views are:

- Identifying clearly the purpose of the funds;

- Directing managers to apply funds as specified by donors;

- Assisting managers to make decisions on project funding by seeing if they have enough funds for a specific purpose; and

- Improving comparison between charities. 
There is a consensus amongst interviewees that restricted funds should refer to those funds that the donors have put specific restrictions on the use of the funds. Two interviewees express the view that the accounting for restricted funds will enable donors to see that their money has been applied as donated.

This finding supports Bird and Morgan-Jones (1981) who identify many different titles of funds used by charities: general fund, accumulated fund, capital fund, special fund, trust fund, restricted fund, defined purpose fund, earmarked fund, and endowment fund. Bird and Morgan-Jones (1981) also recommend a standard terminology for those different types of funds, and they generally categorise funds into unrestricted and restricted. They further classify restricted funds into (1) endowment funds, (2) building and equipment funds, and (3) restricted revenue funds.

In the United Kingdom the recommendations by Bird and Morgan-Jones (1981) has been acted on by the publication of UK SORP 2005 Appendix 1, Paragraph 27 (Charity Commission, 2005) which defines a "fund" as:

A pool of resources, held and maintained separately from other pools because of the circumstances in which the resources were originally received or the way in which they have subsequently been treated. At the broadest level a fund will be one of two kinds: a restricted fund or an unrestricted fund.

SORP 2005 (Charity Commission, 2005) further categorises funds into unrestricted funds and re- stricted funds/special trusts. Unrestricted funds are funds that are expendable at full discretion of the trustees, whereas restricted funds are funds that are subject to limitation imposed by the donors (Charity Commission, 2005).

\subsection{Treatment of fixed assets}

Fixed assets either acquired by purchase or gift should be capitalised and depreciated appropriately over their useful life. The current practice of not capitalising and depreciating fixed assets in charities is considered unacceptable. 
This has been acted on in the United States where the American Institute of Certified Public Accountants (AICPA) in their Not-for-Profit Organizations (AICPA, 2006), Paragraph 9.05 have pre-scribed that the "contributions of property and equipment should be recognized at fair value"

It is also interesting to note in the United Kingdom that before a prescribed method of accounting for fixed assets $22 \%$ of charities expensed their fixed assets and $40 \%$ did not depreciate their fixed assets (Bird and Morgan-Jones, 1981). Since the enactment of the SORPs (Charity Commission, 2005) there has been an almost $100 \%$ compliance on capitalizing and depreciating (Connolly and Hyndman, 2000). Hopefully similar findings will take place in New Zealand with the release and acceptance of NZICA's (2006) Not for Profit Financial Reporting Guide.

\subsection{Accounting basis}

Donations should only be recognised as revenue when they are received or strongly committed e.g. direct debit or automatic payment. This means a modified accrual basis may be appropriate for the treatment of donations. However, there may be a problem gaining acceptance of this practice among the charities, resulting in even more inconsistency and incomparability.

\subsection{Fund raising expenses}

Some charities may allocate a significant portion of administration costs to fund-raising projects, whereas other charities may allocate part or none of the administration costs to fund-raising projects. One of the motivations of allocating administration costs to fundraising projects may be trying to appeal to the donors for a lack of funds. It has to be admitted that comparability between charities should be improved by providing some guidance to charities as how to allocate the administration costs to fund-raising activities and ideally a consensus needs to be made on the appropriate percentage coverage that would be seen as a good benchmark for charities to achieve. This will ensure contributors know what portion of their donation goes to the beneficiary.

\section{Conclusion}


Our research has allowed us to draw several conclusions, which could greatly contribute to a better understanding of the state of the financial accounts of charities in New Zealand. Part of the problem is to achieve some standardisation of terms and practices among charities. Specifically, we recommend first: that funds be identified as either restricted or unrestricted. Second, that all assets acquired be capitalised and depreciated. Third, that charities adopt a modified accrual accounting basis so that donations are only recognised when received as cash. Finally, some standardisation of overhead allocation is established to apply to all revenues. To achieve this more in-depth interviews will need to take place.

In total, these measures will assist in achieving the primary goal of improving the transparency and understandability of the financial accounts of charities. Bearing in mind what the ASB (2005) stated "It may not always be possible to present information in a way that can be understood by all users" (ASB, 2005, p. 52). Even auditors who consider that they have charity expertise failed to ensure that charities in the United Kingdom were complying with the appropriate charity reporting requirements (Palmer, Isaacs, D'Silva, 2001). However, to achieve the goal of transparency we need to ensure that the majority of users understand what they are reading. While other improvements are possible, if the accounting treatments in the four areas identified result in some standardisation and removal of ambiguities worthwhile progress would have been made.

\section{REFERENCES}

American Institute of Certified Public Accountants (2006) Not-for-Profit Organizations, New York, American Institute of Certified Public Accountants.

American Accounting Association (1966), A Statement of Basic Accounting Theory, Sarasota, American Accounting Association.

Accounting Standards Board (2005) "Statement of Principles for Financial reporting: Proposed interpretation for public benefit entities", Exposure draft, London, Accounting Standards Board.

Bird, P. and Morgan-Jones, P. (1981) Financial Reporting by Charities, London, The Institute of Chartered Accountants of England and Wales. 
Charities Act (2005)

Charities Commission (2006a) A Guide to the Charities Act, Wellington, Charities Commission.

Charities Commission (2006b) "Registration of New Zealand charities", LawTalk, Vol 674, No $8, p 8$.

Charities Commission (2006c) Statement of Intent 2006-2009, Wellington, Charities Commission.

Charities Commission (2006d) Fact Sheet 10: Annual Returns under the Charities Act, Wellington, Charities Commission.

Charities Commission (2006e), Glossary, Wellington, Charities Commission.

Charity Commission (2004) RS8 - Transparency and Accountablity, London, Charity Commission. 24

Charity Commission (2005) Accounting and reporting by Charities: Statement of Recommended Practice, London, Charity Commission.

Connolly, C. \& Hyndman, N. (2000), "Charity accounting: An empirical analysis of the impact of recent changes", British Accounting Review, Vol. 32, pp. 77-100.

Cullen, M. and Dunne, P. (2006), Tax incentives for giving to charities and other nonprofit organisations, Wellington, Inland Revenue Department.

Financial Accounting Standards Board (1980), “No. 4 Objectives of Financial Reporting by Nonbusiness Organisations", in Statement of Financial Accounting Concepts, Stamford, Financial Accounting Standards Board.

Fisher, C. (2006), "Sector faces unique challenges", Chartered Accountants Journal, pp. 2729.

Framjee, P. (2004) “Performance counts”, Accountancy, Vol. 134, No. 1334, pp. 88-89. 
Henderson, M. (2002), "A charitable distrust", Sunday Start Times.

Herzlinger, R. E. and Sherman, H. D. (1980), “Advantages of fund accounting in 'nonprofits'”, Harvard Business Review, pp. 94-105.

Hines, A. and Jones, M. J. (1992), "The impact of SORP2 on the UK charitable sector. An empirical study", Financial Accountability and Management, Vol. 8, No. 1, pp. 49-67.

Hyndman, N. (1990), "Charity Accounting - An empirical study of the information needs of contributors to UK fund raising charities", Financial Accountability and Management, Vol. 6, pp. 295-307.

Hyndman, N. (1991), "Contributors to Charities - A comparison of their information needs and the perceptions of such by the providers of information", Financial Accountability and Management, Vol. 7, pp. 69-82.

Income Tax Special Purposes Commissioners v Pemsel, (1891), AC 531

Incorporated Societies Act (1908).

Inland Revenue Department (2005a), About taxes for non-profit organisations, Wellington, Inland Revenue Department.

Inland Revenue Department (2005b), "The Charities Act 2005 - Tax Implications", Inland Revenue Department Tax Information Bulletin, Vol. 17, pp. 58-61.

Income Tax Act (2004)

McLay, D. (2006), "New climate brings challenges in NFP sector", Chartered Accountants Journal, pp. 21-23.

Ministry of Economic Development (2005) Charitable Trusts, Wellington, Ministry of Economic Development. Available http://www.societies.govt.nz/caddocts/F/FS_Charitable_Trusts.html. 26 
Morse, J. M. (1995), "The significant of saturation”, Qualitative health Research, Vol. 5, No. 2, pp. 147-149.

Newberry, S. (1992) Special issues of accounting for charities in New Zealand, Christchurch, Susan Newberry.

New Zealand Institute of Chartered Accountants (1993) Statement of Concepts for General Purpose Financial Reporting, Wellington, New Zealand Institute of Chartered Accountants.

New Zealand Institute of Chartered Accountants (2004a), New Zealand International Accounting Standard 1: Presentation of Financial Statement, Wellington, New Zealand Institute of Chartered Accountants.

New Zealand Institute of Chartered Accountants (2004b), New Zealand International Accounting Standard 36: Impairment of Assets, Wellington, New Zealand Institute of Chartered Accountants.

New Zealand Institute of Chartered Accountants (2005), Submission to the Ministry of Economic Development on the review of the Financial Reporting Act 1993, Wellington, New Zealand Institute of Chartered Accountants.

New Zealand Institute of Chartered Accountants (2006) Not for Profit Financial Reporting Guide, Wellington, New Zealand Institute of Chartered Accountants. 27

Palmer, P., Isaacs, M. and D’Silva. K. (2001), “Charity SORP compliance - findings of a research study", Managerial Auditing Journal, Vol. 16, No. 5, pp 255-262.

Radio New Zealand (2005) New Zealand government says it has paid what it pledged to help tsunami, Wellington.

Saywell, V. (2006), "Registering under the Charities Act: should you be one entity or several?", Chartered Accountants Journal, pp. 60-63.

Siveter, L. (2003), "Toward better oversight of charities", The Independent. 
Siveter, L. (2004), "Strong boards build strong charities", The Independent.

Statistics New Zealand (2006), "Identifying Non-Profit Institutions in New Zealand, Wellington, Statistics New Zealand.

Tennant, M., Sanders, J., O’Brien, M. and Castle, C. (2006), “Defining the Non Defining the Non- profit Sector: New Zealand", Working Papers of the Johns Hopkins Comparative Non-profit Sector project, Baltimore, John Hopkins University.

United Nations (2003), Handbook on Non-Profit Institutions in the System of National Accounts, New York, United Nations.

United Nations (2006), Update: Handbook on Non-profit Institutions in the System of National Accounts, The Institute for Policy Studies of the Johns Hopkins University, Washington.

Wacht, R. F. (1991), Financial management in non profit organizations, Atlanta, Georgia State University Business Press.

Williams, S. and Palmer, P. (1998), "The state of charity accounting - developments, improvements and continuing problems", Financial Accountability and Management, Vol 14, No. 4, pp. 265-279.

Wilson, M. (2004), "Review of the Financial Reporting Act 1993", Chartered Accountants Journal, pp. 16-17. 29 